\title{
CHARACTERS OF A NEW AMERICAN FAMILY OF PASSERINE BIRDS.
}

\author{
By Robert Ridgway, \\ Curator of the Department of Birds.
}

IN "The Auk", ${ }^{1}$ Mr. F. A. Lucas, curator of the department of comparative anatomy in the National Museum, has called attention to the notable characters presented in the skull of the genus Procnias, Illiger, at the same time remarking that my proposed establishment of a new family for its reception "is certainly warranted by the cranial characters of the genus." Although I had already drawn up a diagnosis of the external characters of the family, circumstances have until now prevented its publication. The diagnosis is herewith presented, the osteological and pterylographical characters being given in a separate paper by Mr. Lucas. ${ }^{2}$

\section{Family PROCNIATID A.}

SWALLOW-TANAGERS.

Procniatina [Tanagrida] Sclater, Cat. Am. Birds, p. 54, 1862. (Subfamily.)

External characters.-Bill triangular, depressed, extremely broad at base but compressed at tip, the lateral outline changing from convex basally to concave terminally; gape very long, extending to beneath anterior angle of eye; gonys less than half as long as commissure and much less than breadth of bill at base; culmen sharply ridged, strongly recurved terminally; tip of maxilla slightly notehed; nostrils exposed, very small, circular, surrounded by a slightly raised rim. Tarsi short (about as long as commissure, shorter than middle toe with claw), scutellate anteriorly, caligate posteriorly, the hinder margin contracted into a sharp edge; lateral claws not reaching base of middle claw; hind claw - much stouter than middle claw. Wings long (more than five times as

${ }^{1}$ April, 1895, p. 186.

${ }^{2}$ Mr. Lucas' paper (Proc. U. S. Nat. Mus., XVIII, 1895, p. 451) follows immediately after the present one.

Proceedings of the United States National Museum, Vol. XVIII-No. 1076.

Proc. N. M. $95-29$ 
long as tarsus); tip of longest primary exceeding that of ninth by a little more than length of tarsus and half of middle toe; second and third quills longest, first and fourth but little shorter. Tail more than half as long as wing, nearly even or very slightly emarginated. Plumage blended, glossy; remiges and rectrices very firm, almost rigid. Color mainly blue (greenish in female), the sides and flanks barred with black. Nest in holes; eggs pure white.

Range.-Neotropical region (Brazilian and Amazonian provinces, and northeastern portion of Colombian province). 


\section{$2 \mathrm{BHL}$ Biodiversity Heritage Library}

Ridgway, Robert. 1896. "Characters of a new American family of passerine birds." Proceedings of the United States National Museum 18(1076), 449-450. https://doi.org/10.5479/si.00963801.1076.449.

View This Item Online: https://www.biodiversitylibrary.org/item/32799

DOI: https://doi.org/10.5479/si.00963801.1076.449

Permalink: https://www.biodiversitylibrary.org/partpdf/5719

\section{Holding Institution}

Smithsonian Libraries

\section{Sponsored by}

Smithsonian

\section{Copyright \& Reuse}

Copyright Status: NOT_IN_COPYRIGHT

This document was created from content at the Biodiversity Heritage Library, the world's largest open access digital library for biodiversity literature and archives. Visit BHL at https://www.biodiversitylibrary.org. 